\title{
Isozyme and Morphological Variation in a Cornus florida L. Provenance Plantation Representing Geographically Diverse Populations
}

\author{
Alexander Fernandez ${ }^{1}$, Robert E. Schutzki² ${ }^{2}$ and James F. Hancock ${ }^{3}$ \\ Department of Horticulture, Michigan State University, East Lansing, MI 48824-1325
}

\begin{abstract}
Additional index words. electrophoresis, flowering dogwood, principal component analysis, population genetics
Abstract. Starch gel electrophoresis and principal component (PC) analysis were used to determine the levels of genetic variation and the relationship between morphology and geographic origin for Cornus florida (flowering dogwood) populations in a Michigan provenance plantation. The populations are representative of the species' geographic distribution, ranging from Texas to Georgia and north to Connecticut and Michigan. Allelic variation at 11 loci encoded by 5 enzymes was very low in comparison to other plant species. On average, populations displayed 1.16 alleles per locus, 9.89\% of loci polymorphic, with an observed heterozygosity value of 0.048 . Genetic identify values ranged from 0.961 to 1.00 and displayed no relationship with geographic origin. While the isozyme analysis revealed little genetic variation, the PC analysis revealed a considerable amount of morphological variation. Most variation (83.3\%) in leaf and flower bud morphology was explained by three PCs. Leaf characters revealed no relationship with geographic origin. However, flower bud size and number of florets decreased with changes in latitude from northern, central, and southern populations, respectively. The relationship between flower bud size and latitude suggests an adaptive response to photoperiod throughout the species' geographic range.
\end{abstract}

Interest in measuring genetic variation of native Cornus florida L. $(2 \mathrm{n}=2 \mathrm{x}=22)$ populations has been in response to numerous reports of disease, insect, and cold hardiness problems affecting trees in landscapes and native populations. Lack of variation in flower bud hardiness in C.florida with southern origins is cited as a major cause of floral death or deformation in northern landscapes (Dirr, 1990; Heatley, 1986). Unfortunately, few investigations have been reported on the levels of phenotypic and genetic variation in C.florida. Santamour and McArdle (1989) indicated a lack of genetic variation in anthracnose resistance for $C$. florid $a$ with no correlation between resistance and geographic origin. At the DNA level, Culpepper et al. (1991) investigated the genus Cornus utilizing restriction fragment length polymorphisms (RFLPs) and found high levels of genetic diversity between Cornus species, but low levels of genetic diversity between $C$. florida cultivars.

Levels of genetic variation in plant populations are influenced by the life history and ecological features of a species (Brown, 1979; Hamrick et al., 1979; Loveless and Hamrick, 1984). Species with wide distributions, high outcrossing rates, wind pollination, wind dispersal of seed, high fecundities, long generation times, and residents of late successional habitats generally maintain higher levels of genetic variation within populations than between them (Hamrick et al., 1979).

Cornus florida is a perennial angiosperm that possesses many of the variation-inducing traits with the notable exceptions of pollination and seed dispersal mechanisms. Cornus florida is insect pollinated (Gunatilleke and Gunatilleke, 1984) and seed is dispersed through animal ingestion and gravity (Elias, 1987). Both of these life-history traits would be expected to increase the genetic

Received for publication 12 June 1995. Accepted for publication 3 Nov. 1995. Special thanks to J. Kielbaso, Dept. of Forestry, and G. Kowalewski, Kellogg Forest, Michigan State Univ., for their cooperation and the use of the Cornus plantation. The cost of publishing this paper was defrayed in part by the payment of page charges. Under postal regulations, this paper therefore must be hereby marked advertisement solely to indicate this fact.

${ }^{1}$ Graduate research assistant.

${ }^{2}$ Associate professor.

${ }^{3}$ Professor. variation among populations while reducing variation within populations (Loveless and Hamrick, 1984).

This paper presents results of an isozyme and morphological evaluation of native $C$. florida trees in a provenance plantation. The objectives of the study were to determine the levels of genetic variation in native populations and assess the relationships among geographic origin, allelic profiles, and morphometric traits.

\section{Materials and Methods}

Three $C$. florida provenance plantations in close proximity were used in this study. The plantations were established in 1975 by Wright and Kielbaso, Dept. of Forestry, Michigan State Univ., and are located at the Kellogg Forest in Augusta, Mich. Cooperators collected open-pollinated seeds in native populations representative of the flowering dogwood's geographic range (Table 1). Of the 24 populations used in this study, 10 are represented by seeds collected from a single tree per population and the remaining 14 are represented by seeds collected from multiple trees per population (Table 2). Plantation design, establishment, and maintenance is described by Heatley (1986).

For sampling purposes, populations represented in the provenance plantations were collected by state of origin. Within each state, an attempt was made to sample five individual trees from two distinct populations. The minimum distance separating populations was about 45 miles. Due to tree mortality, not all states were represented by two populations and five trees per population within the isozyme evaluation and principal component analysis (Tables 1 and 2). A total of 111 trees were examined, representing 24 populations across 15 states. A Texas population was represented in the principal component (PC) analysis but not in the isozyme evaluation.

Branches with dormant vegetative terminal buds were collected for electrophoresis on 8 Apr. 1993. The twigs were sealed in plastic bags and stored on ice for transport to East Lansing, Mich. Samples were then stored at $5 \mathrm{C}$ for a maximum of 2 days until buds were removed and enzyme extractions completed.

About $8 \mathrm{mg}$ of dormant buds ( 8 to 10 terminal buds) were 
removed from the twigs and ground in a chilled mortar and pestle. Axillary buds were used when terminal bud material was limited. Extraction for all enzymes was achieved using techniques outlined by Hokanson et al. (1993).

Electrophoresis. Investigations of five enzyme systems and two gel-electrode buffer systems yielded 11 well-resolved putative loci. Malate dehydrogenase (MDH, EC 1.11.1.7) and isocitrate dehydrogenase (IDH, EC 1.1.1.42) were resolved using morpholinecitrate $\mathrm{pH} 6.1$ buffer (Clayton and Tretiak, 1972). Gels (10 mm thick) of $11 \%$ starch were run at $50 \mathrm{~mA}$ for $1 \mathrm{~h}$ and increased to 55 to $65 \mathrm{~mA}$ for $5 \mathrm{~h}$. Esterase (EST, EC 3.1.1.2), leucine amino peptidase (LAP, EC 3.4.11.1), and alcohol dehydrogenase (ADH, EC 1.1.1.1) were resolved using lithium borate Tris citrate $\mathrm{pH} 8.3$ buffer (Scandalios, 1969). Gels (10 mm thick) of $11 \%$ starch were run at $75 \mathrm{~mA}$ until $275 \mathrm{~V}$ were reached. The system was then maintained at $275 \mathrm{~V}$ for a total running time of $6 \mathrm{~h}$ at about $0 \mathrm{C}$.

Enzyme staining protocols were obtained from Vallejos (1983) for MDH, Soltis et al. (1983) for IDH and LAP, and Wendel and Weeden (1989) for EST and ADH. After staining was complete, gels were rinsed first with water, then with $1 \%$ acetic acid solution. Gels were fixed in 50\% ethanol solution, placed in zip-lock bags, and stored at $4 \mathrm{C}$ until they could be analyzed and photographed.

Scoring of those enzymes with multiple loci was completed according to Hokanson et al. (1993). Locus and allele predictions of the observed banding patterns are based on the predictability of enzyme structure and the expected number of loci from previous isozyme investigations (Kephart, 1990). A genetic analysis was not completed. Loci and allele predictions, therefore, are reported as putative. Levels of variation were determined based on measures of percent polymorphic loci, allele frequencies, mean alleles per locus, and levels of heterozygosity. A locus was considered polymorphic if the frequency of the most common allele did not exceed 0.95. Genetic identity (I) according to Nei (1978) was calculated between populations, using the allele frequency data.

Quantitative analysis of leaf and flower bud characters. Flower buds and leaves were collected from trees located in the same three provenance plantations described earlier (Table 1). Leaf sampling strategy followed the recommendations described by Blue and Jensen (1988) for species and population comparisons. Five fully expanded leaves were randomly selected on 25 July 1993 from twigs located in the southeast quadrant of the upper one-third portion of each tree. The leaves were pressed and transported to East Lansing. On 9 Nov. 1993, 10 flower buds were randomly collected from the area of the tree previously described. The flower buds were sealed in plastic bags and transported on ice to East Lansing, Mich.

Data for nine leaf characters and three flower bud characters were recorded for each tree. Leaf surface area was calculated using a Delta-T Devices area measurement system. Leaf width and length measurements were recorded in millimeters by overlaying a transparent grid on pressed leaves. Flower bud width and length measurements were recorded in millimeters using Fowler \& NSK Max-Cal electronic digital calipers. Statistical analysis was conducted on the means for each of the 12 variables within a population. SAS (SAS Institute, Cary, N.C.) was used to perform principal component analysis on the 12-variable correlation matrix.

\section{Results}

Electrophoretic survey. Five enzyme systems resolved clearly and were interpreted for this study. The enzyme systems encoded 11 putative loci with a total of 16 putative alleles. Of the 11 loci examined, Lap-1,Est-1, and Est-2 were the only ones that were polymorphic. The remaining eight loci were monomorphic with

Table 1. State of collection, populations designations, number of individuals, latitude designations, latitude and longitude of 24 Cornus florida populations used for principal component analysis.

\begin{tabular}{|c|c|c|c|c|c|}
\hline State & $\begin{array}{l}\text { Population } \\
\text { ID }\end{array}$ & $\begin{array}{c}\text { No. of } \\
\text { individuals }\end{array}$ & $\begin{array}{l}\text { Lat. } \\
\text { ID }\end{array}$ & Lat. & Long. \\
\hline$\overline{\mathrm{AL}-1}$ & 1 & 4 & 3 & $33^{\circ} 00^{\prime}$ & $86^{\circ} 30^{\prime}$ \\
\hline CT-1 & 2 & 5 & 1 & $41^{\circ} 60^{\prime}$ & $73^{\circ} 00^{\prime}$ \\
\hline GA-1 & 3 & 3 & 3 & $33^{\circ} 30^{\prime}$ & $83^{\circ} 42^{\prime}$ \\
\hline GA-2 & 4 & 2 & 3 & $33^{\circ} 07^{\prime}$ & $84^{\circ} 30^{\prime}$ \\
\hline IL-1 & 5 & 5 & 2 & $37^{\circ} 80^{\prime}$ & $89^{\circ} 30^{\prime}$ \\
\hline IL-2 & 6 & 4 & 2 & $37^{\circ} 28^{\prime}$ & $88^{\circ} 42^{\prime}$ \\
\hline IN-1 & 7 & 5 & 2 & $38^{\circ} 17^{\prime}$ & $86^{\circ} 33^{\prime}$ \\
\hline IN-2 & 8 & 5 & 2 & $38^{\circ} 40^{\prime}$ & $85^{\circ} 10^{\prime}$ \\
\hline KY-1 & 9 & 5 & 2 & $37^{\circ} 40^{\prime}$ & $86^{\circ} 60^{\prime}$ \\
\hline $\mathrm{KY}-2$ & 10 & 5 & 2 & $37^{\circ} 27^{\prime}$ & $83^{\circ} 10^{\prime}$ \\
\hline MD-1 & 11 & 5 & 2 & $39^{\circ} 60^{\prime}$ & $76^{\circ} 60^{\prime}$ \\
\hline MD-2 & 12 & 5 & 2 & $39^{\circ} 00^{\prime}$ & $75^{\circ} 80^{\prime}$ \\
\hline MI-1 & 13 & 5 & 1 & $42^{\circ} 50^{\prime}$ & $84^{\circ} 40^{\prime}$ \\
\hline MI-2 & 14 & 5 & 1 & $42^{\circ} 45^{\prime}$ & $84^{\circ} 23^{\prime}$ \\
\hline MO-1 & 15 & 5 & 2 & $37^{\circ} 30^{\prime}$ & $91^{\circ} 51^{\prime}$ \\
\hline MO-2 & 16 & 5 & 2 & $38^{\circ} 80^{\prime}$ & $91^{\circ} 80^{\prime}$ \\
\hline $\mathrm{OH}-1$ & 17 & 5 & 1 & $40^{\circ} 47^{\prime}$ & $81^{\circ} 54^{\prime}$ \\
\hline $\mathrm{OH}-2$ & 18 & 5 & 1 & $40^{\circ} 40^{\prime}$ & $80^{\circ} 56^{\prime}$ \\
\hline PA-1 & 19 & 5 & 1 & $41^{\circ} 35^{\prime}$ & $79^{\circ} 16^{\prime}$ \\
\hline TN-1 & 20 & 4 & 2 & $36^{\circ} 12^{\prime}$ & $84^{\circ} 50^{\prime}$ \\
\hline TX-1 & 21 & 3 & 3 & $31^{\circ} 00^{\prime}$ & $93^{\circ} 80^{\prime}$ \\
\hline VA-1 & 22 & 4 & 2 & $37^{\circ} 50^{\prime}$ & $78^{\circ} 60^{\prime}$ \\
\hline VA-2 & 23 & 5 & 2 & $37^{\circ} 50^{\prime}$ & $80^{\circ} 40^{\prime}$ \\
\hline WV-1 & 24 & 5 & 2 & $39^{\circ} 30^{\prime}$ & $78^{\circ} 25^{\prime}$ \\
\hline
\end{tabular}


Table 2. Population variability estimates for 23 Cornus florida populations evaluated for isozyme diversity at 11 loci encoded by five enzymes. $^{\mathrm{Z}}$

\begin{tabular}{|c|c|c|c|c|c|}
\hline Population & $\begin{array}{c}\text { No. of } \\
\text { trees }\end{array}$ & $\begin{array}{l}\text { Collection } \\
\text { method }^{\mathrm{y}}\end{array}$ & A & $\mathrm{P}$ & $\mathrm{H}_{\mathrm{Ob}}$ \\
\hline$\overline{\mathrm{AL}-1}$ & 5 & $\mathrm{M}$ & 1.3 & 18.2 & $0.055(0.039)^{x}$ \\
\hline CT-1 & 5 & S & 1.3 & 18.2 & $0.145(0.098)$ \\
\hline GA-1 & 4 & M & 1.1 & 9.1 & $0.023(0.023)$ \\
\hline GA-2 & 3 & M & 1.2 & 9.1 & $0.091(0.091)$ \\
\hline IL-1 & 5 & M & 1.1 & 9.1 & $0.055(0.055)$ \\
\hline IL-2 & 4 & $\mathrm{~S}$ & 1.2 & 9.1 & $0.091(0.091)$ \\
\hline IN-1 & 5 & M & 1.0 & 0.0 & $0.000(0.000)$ \\
\hline $\mathrm{IN}-2$ & 5 & M & 1.2 & 9.1 & $0.055(0.055)$ \\
\hline KY-1 & 5 & S & 1.2 & 9.1 & $0.055(0.055)$ \\
\hline $\mathrm{KY}-2$ & 5 & S & 1.0 & 0.0 & $0.000(0.000)$ \\
\hline MD-1 & 5 & S & 1.1 & 9.1 & $0.091(0.091)$ \\
\hline MD-2 & 5 & S & 1.1 & 9.1 & $0.036(0.036)$ \\
\hline MI-1 & 5 & S & 1.1 & 9.1 & $0.018(0.018)$ \\
\hline MI-2 & 5 & M & 1.1 & 9.1 & $0.036(0.036)$ \\
\hline MO-1 & 5 & M & 1.2 & 9.1 & $0.036(0.036)$ \\
\hline MO-2 & 5 & M & 1.2 & 9.1 & $0.091(0.091)$ \\
\hline $\mathrm{OH}-1$ & 5 & M & 1.2 & 18.2 & $0.109(0.091)$ \\
\hline $\mathrm{OH}-2$ & 5 & M & 1.3 & 18.2 & $0.091(0.091)$ \\
\hline PA-1 & 5 & M & 1.1 & 9.1 & $0.018(0.018)$ \\
\hline TN-1 & 5 & S & 1.2 & 9.1 & $0.073(0.073)$ \\
\hline VA-1 & 5 & $S$ & 1.1 & 9.1 & $0.091(0.091)$ \\
\hline VA-2 & 5 & M & 1.2 & 9.1 & $0.073(0.073)$ \\
\hline WV-1 & 5 & $\mathrm{~S}$ & 1.1 & 9.1 & $0.091(0.091)$ \\
\hline Means & 4.83 & & 1.16 & 9.89 & 0.62 \\
\hline
\end{tabular}

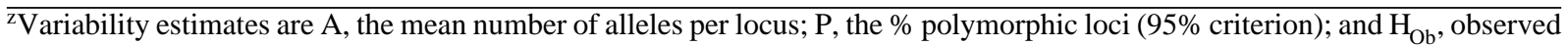
heterozygosity.

${ }^{\mathrm{y}}$ Seed collection methods are $\mathrm{S}$ for single tree collections and $\mathrm{M}$ for multiple tree collections.

${ }^{\mathrm{x}}$ Numbers in parenthesis indicate standard error.

IDH encoding two homozygous loci and both MDH and ADH encoding three homozygous loci. The average number of alleles per locus (A) was very low (1.16), with a range of 1.0 to 1.3 (Table 2). The mean percentage of polymorphic loci $(\mathrm{P})$ for all populations was only $9.89 \%$. The percent polymorphic loci for individual populations ranged from $0 \%$ to $18.2 \%$.

Only two populations, AL- 1 and CT-1, displayed unique alleles. Est $-2^{2}$ appeared in a single heterozygous individual of the AL1 population and Lap- $I^{1}$ was evident in two heterozygous individuals of the CT-1 population. Identity values (I) for all populations ranged from 0.961 to 1.000 . The greatest divergence in pairwise comparisons $(\mathrm{I}=0.961)$ was found in comparisons of CT-1 with MD-1, VA-1, and WV-1.

Ten populations studied are represented by open-pollinated seed sources collected from a single tree (Table 2). The maternal bias due to this collection method would be expected to lower the electrophoretically detectable variation within these populations. To determine the variation between the two collection methods, the populations were separated into single-tree collections and multiple-tree collections and analyzed separately. Contrary to expectations, there was a higher level of heterozygosity within populations represented by single-tree collections. The differences in alleles per locus and polymorphic loci between the two collection methods were 0.03 and $1.4 \%$, respectively. Direct count heterozygosities for single-tree collections revealed a slight increase in heterozygosity with a difference of 0.013 .

PC analysis. Eighty-three percent of the total variation in the 12 leaf and flower bud characters was explained by three PCs (Table 3). Forty-eight percent of the total variance was explained by PC1.
Leaf surface area, leaf length, primary veins, and the various leaf width measurements all had relatively high positive loadings. The three flower bud characteristics and petiole length were not signifi-

Table 3. Eigenvectors, eigenvalues and percentage of total variance for the three principal components (PCs) accounting for $83.3 \%$ of the total variation from 24 Cornus florida populations in a provenance plantation.

\begin{tabular}{lcrr}
\hline $\begin{array}{l}\text { Morphology and } \\
\text { character }^{2}\end{array}$ & PC1 & PC2 & PC3 \\
\hline PL & 0.117 & -0.186 & 0.427 \\
LL & 0.315 & 0.140 & -0.000 \\
PV & 0.312 & -0.118 & 0.435 \\
LWW & 0.395 & -0.027 & -0.214 \\
LW25 & 0.339 & -0.026 & -0.380 \\
LW50 & 0.399 & -0.022 & -0.193 \\
LW75 & 0.352 & -0.058 & -0.111 \\
SA & 0.406 & -0.084 & -0.022 \\
LWB & 0.234 & -0.096 & -0.585 \\
BW & 0.073 & 0.581 & 0.055 \\
BL & 0.065 & 0.590 & 0.108 \\
FLO & 0.081 & 0.474 & 0.135 \\
Eigenvalue & 5.800 & 2.606 & 1.596 \\
Variance $(\%)$ & 48.3 & 21.7 & 13.3 \\
\hline
\end{tabular}

$\overline{{ }^{2} \mathrm{PL}}=$ petiole length, $\mathrm{PV}=$ number of primary veins, $\mathrm{LL}=$ leaf length, $\mathrm{LWW}$ $=$ leaf width at widest point, LW25 = leaf width at $25 \%$ of length, LW50 = leaf width at $50 \%$ of length, LW75 = leaf width at $75 \%$ of length, LWB = distance from widest point to leaf base, $\mathrm{SA}=$ leaf surface area, $\mathrm{BW}=$ flower bud width, BL) flower bud length, FLO = number of florets per bud. 


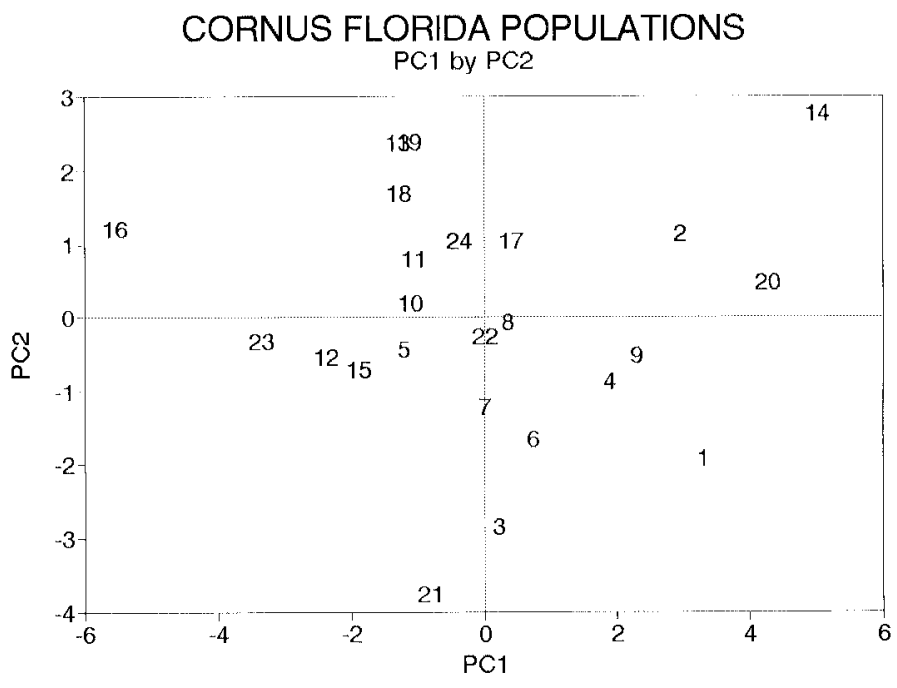

Fig. 1. Relationship between eigenvector loadings derived from leaf and flower bud characters with Cornus florida populations listed in Table 4. PC1 (x axis) accounted for $48 \%$ of the total variation and PC2 (y axis) accounted for $22 \%$.

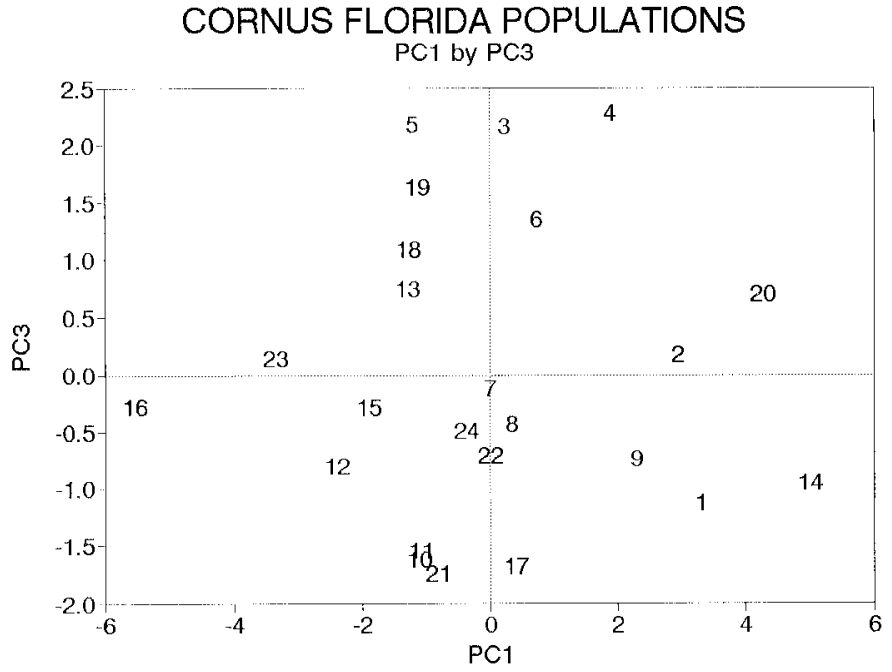

Fig. 2. Relationship between eigenvector loadings derived from leaf and flower bud characters with Cornus florida populations listed in Table 4. PC1 (x axis) accounted for $48 \%$ of the total variation and PC3 (y axis) accounted for $13 \%$.

cantly correlated to leaf measurements and contributed little to PC1. In PC2, flower bud length and flower bud width had high positive loadings and were highly correlated with the number of florets accounting for nearly $22 \%$ of the total variation. No leaf measurements were significantly correlated with the flower bud characteristics in PC2. Thirteen percent of the total variance was accounted for by PC3. Petiole length, leaf length, and leaf width at base had the highest positive loadings in PC3, contrasted with negative loadings from the remaining leaf width measures. The remaining nine PCs accounted for $17 \%$ of the total variance with each accounting for $<8 \%$.

The relationships between populations, geographic factors, and the variance explained by the PCs were graphically visualized by plotting the three most variable PCs against each other. In Figs. 1 and 2, PC1 is represented on the $\mathrm{x}$-axis in comparison with PC2, and PC 3 on the y-axis. The remaining biplot combinations displayed similar patterns evident in these biplots. Distinct patterns or clustering of populations were not obvious with any of the PC combinations. Figure 1 illustrates the correlation between leaf size and flower bud size, where leaf size is represented on the $\mathrm{x}$-axis (PC1), and flower bud size on the y-axis (PC2). About half of the populations clustered near the center of the graph, with moderate leaf and flower bud sizes, and the remaining populations exhibited unique characteristics. Population MI-2 (14), TX-1 (21), and MO2 (16) displayed the most atypical characteristics. Population MI2 possessed the largest leaves and flower buds, TX-1 had moderate leaf sizes and the smallest flower buds, and MO-2 possessed the smallest leaves and moderately large flower buds (Table 4). The lack of correlation between leaf size and flower bud size is visualized in Fig. 1.

PC1 by PC3 exhibited a scattered pattern similar to the pattern found in Fig. 1, with no clustering of populations. Although no distinct patterns were discernible, the biplot can be used to distinguish atypical populations. For example, in Fig. 2, IL-1 (5), GA1 (3), and GA-2 (4) all displayed moderate leaf sizes as determined by PC 1 but they had unique leaf shapes determined by PC 3 . These populations on average had longer leaves with wider leaf bases (positive loadings) and narrow widths at $25 \%$ of the leaf length (negative loading). Therefore, the overall leaf shape can be characterized as a long leaf which tapers off quickly from a wide leaf base.

To determine the relationship between the variance found for the 12 characteristics and geographic origin, numeric designations were assigned to each population according to latitude alone, and latitude by longitude (Table 1). Patterns in biplots with latitude by longitude designations were similar but not as obvious as latitude alone and are not included in this report.

Distinct clustering of latitude groups was most evident when PC2 was included on an axis. Northern populations had the largest flower buds and southern populations had the smallest flower buds with the central populations clustered between the two. In Fig. 3, where PC2 is plotted on the y-axis against PC1 on the x-axis, populations with the most northern latitudes exhibited large positive values for $\mathrm{PC} 2$, populations with central latitudes exhibited moderate values, and the most southern populations displayed large negative values. Overall leaf size, represented by PC1, appeared to have no relationship with latitude.

Clustering of latitude groups in biplots with PC3 or PC4 on an axis was apparent only when plotted against PC2. Therefore, distinct latitudinal relationships were distinguished by $\mathrm{PC} 2$, which accounted for $22 \%$ of the total variance.

\section{Discussion}

Total isozyme diversity. The level of isozyme diversity revealed through electrophoresis of five enzymes indicates that $C$. florida has a very low degree of genetic variation, $1.16(\mathrm{~A})$ and $9.89 \%(\mathrm{P})$, in comparison to other perennial angiosperm species. A similar conclusion was reached by Culpepper et al. (1991) following an investigation of $C$. florida cultivars using RFLP analysis. Investigations of isozyme diversity in Alnus crispa (Bousquet et al., 1987), Camellia japonica (Wendel and Parks, 1985), Robinia pseudoacacia (Surles et al., 1989), and Quercus spp. (Hokanson et al., 1993) revealed ranges of 2.16 to 2.80 alleles per locus with the percent polymorphic loci ranging from $45 \%$ to $71 \%$. Hamrick and Godt (1989) found all plant species studied had an average of 50\% of their loci polymorphic and 1.96 alleles per locus.

While the isozyme analysis revealed little genetic variation, the PC analysis uncovered a considerable amount of morphological variation between populations. A distinct association was observed between flower bud size and population latitude (Fig. 3). 
Table 4. Mean data for the 12 morphological characters ${ }^{\mathrm{z}}$ used to determine patterns of variation in 24 Cornus florida populations.

\begin{tabular}{|c|c|c|c|c|c|c|c|c|c|c|c|c|}
\hline Population & $\begin{array}{c}\text { PL } \\
(\mathrm{cm})\end{array}$ & PV & $\begin{array}{l}\mathrm{LL} \\
(\mathrm{cm})\end{array}$ & $\begin{array}{l}\text { LWW } \\
(\mathrm{cm})\end{array}$ & $\begin{array}{c}\mathrm{LW} 25 \\
(\mathrm{~cm})\end{array}$ & $\begin{array}{c}\text { LW50 } \\
(\mathrm{cm})\end{array}$ & $\begin{array}{l}\text { LW75 } \\
(\mathrm{cm})\end{array}$ & $\begin{array}{c}\mathrm{SA} \\
\left(\mathrm{cm}^{2}\right)\end{array}$ & $\begin{array}{c}\text { LWB } \\
(\mathrm{cm})\end{array}$ & $\begin{array}{l}\text { BW } \\
(\mathrm{mm})\end{array}$ & $\begin{array}{c}\text { BL } \\
(\mathrm{mm})\end{array}$ & FLO \\
\hline$\overline{\mathrm{AL}-1}$ & 1.10 & 11.45 & 11.40 & 6.87 & 5.86 & 6.70 & 4.40 & 63.66 & 6.14 & 5.12 & 4.46 & 17.83 \\
\hline CT-1 & 1.15 & 11.00 & 10.73 & 6.76 & 5.14 & 6.68 & 4.98 & 47.00 & 5.46 & 6.79 & 5.54 & 23.40 \\
\hline GA-1 & 1.38 & 10.60 & 11.34 & 6.04 & 4.44 & 5.93 & 4.25 & 42.93 & 5.57 & 4.31 & 3.94 & 19.33 \\
\hline GA-2 & 1.12 & 11.10 & 11.78 & 6.28 & 4.53 & 6.23 & 4.40 & 46.10 & 6.14 & 5.55 & 4.84 & 20.70 \\
\hline IL-1 & 1.30 & 10.76 & 11.01 & 5.58 & 4.42 & 5.52 & 3.71 & 39.00 & 5.34 & 5.80 & 5.21 & 20.00 \\
\hline IL-2 & 1.46 & 10.35 & 10.61 & 6.19 & 4.82 & 6.11 & 4.60 & 44.60 & 5.28 & 5.11 & 4.61 & 20.80 \\
\hline IN-1 & 1.32 & 10.72 & 10.42 & 6.25 & 5.18 & 6.10 & 4.02 & 41.80 & 4.81 & 5.51 & 4.54 & 19.58 \\
\hline IN-2 & 1.21 & 10.92 & 10.36 & 6.16 & 5.22 & 6.08 & 4.28 & 42.08 & 4.82 & 6.04 & 5.30 & 19.86 \\
\hline KY-1 & 1.20 & 11.44 & 10.27 & 6.64 & 5.32 & 6.54 & 4.75 & 46.04 & 5.12 & 5.94 & 4.82 & 19.92 \\
\hline KY-2 & 1.02 & 10.36 & 9.43 & 6.18 & 4.84 & 6.08 & 4.34 & 38.84 & 4.63 & 5.64 & 4.87 & 21.62 \\
\hline MD-1 & 1.03 & 10.96 & 9.36 & 6.00 & 4.92 & 5.92 & 4.20 & 37.92 & 4.62 & 6.45 & 5.36 & 19.84 \\
\hline MD-2 & 1.14 & 10.64 & 9.42 & 5.72 & 4.69 & 5.61 & 3.88 & 35.20 & 4.63 & 5.56 & 4.79 & 18.90 \\
\hline MI-1 & 1.14 & 10.84 & 10.17 & 5.72 & 4.62 & 6.62 & 3.92 & 36.76 & 4.91 & 6.95 & 6.14 & 23.69 \\
\hline MI-2 & 1.11 & 11.76 & 11.19 & 7.23 & 6.20 & 7.07 & 4.64 & 53.16 & 5.12 & 7.51 & 6.80 & 23.72 \\
\hline MO-1 & 1.07 & 10.92 & 9.88 & 5.65 & 4.46 & 5.58 & 4.04 & 36.72 & 4.90 & 5.36 & 4.86 & 18.36 \\
\hline MO-2 & 1.09 & 10.24 & 8.68 & 5.00 & 3.82 & 4.92 & 3.44 & 27.64 & 4.29 & 5.89 & 5.18 & 22.16 \\
\hline OH-1 & 1.18 & 10.32 & 9.79 & 6.54 & 5.62 & 6.39 & 4.27 & 42.80 & 4.50 & 7.03 & 5.61 & 21.30 \\
\hline $\mathrm{OH}-2$ & 1.16 & 10.52 & 10.42 & 5.74 & 4.53 & 5.64 & 3.87 & 38.32 & 5.06 & 6.77 & 5.77 & 23.44 \\
\hline PA-1 & 1.22 & 10.76 & 10.30 & 6.76 & 4.32 & 5.65 & 3.82 & 38.08 & 5.17 & 7.18 & 6.59 & 22.84 \\
\hline TN-1 & 1.34 & 11.60 & 11.27 & 6.94 & 6.69 & 6.80 & 4.80 & 50.05 & 5.45 & 6.35 & 5.49 & 22.85 \\
\hline TX-1 & 1.17 & 10.20 & 9.84 & 6.29 & 5.36 & 6.13 & 4.27 & 41.20 & 4.67 & 2.52 & 3.14 & 19.67 \\
\hline VA-1 & 1.02 & 11.05 & 10.52 & 6.25 & 5.04 & 6.04 & 3.90 & 43.35 & 4.92 & 5.55 & 4.61 & 20.90 \\
\hline VA-2 & 0.99 & 10.52 & 9.85 & 5.34 & 4.07 & 5.26 & 3.79 & 33.80 & 4.96 & 5.67 & 4.90 & 18.64 \\
\hline WV-1 & 1.11 & 10.84 & 9.77 & 6.06 & 4.75 & 5.96 & 4.41 & 39.92 & 4.86 & 6.40 & 5.33 & 22.30 \\
\hline
\end{tabular}

${ }^{\mathrm{z}} \mathrm{PL}=$ petiole length, $\mathrm{PV}=$ number of primary veins, $\mathrm{LL}=$ leaf length, $\mathrm{LWW}=$ leaf width at widest point, LW25 = leaf width at $25 \%$ of length, LW50 $=$ leaf width at $50 \%$ of length, $\mathrm{LW} 75=$ leaf width at $75 \%$ of length, $\mathrm{LWB}=$ distance from widest point to leaf base, $\mathrm{SA}=$ leaf surface area, $\mathrm{BW}=$ flower bud width, BL) flower bud length, FLO = number of florets per bud.

Leaf characteristics were also highly variable but with no apparent relationship with latitude. The variation in flower bud size can be attributed to adaptations for the differences in photoperiodic conditions throughout the geographic range. Similar ecotypic differentiation is known to occur in many woody plant species with large north-to-south ranges (Kozlowski et al., 1991).

The ecotypic variation revealed by PC analysis coincides with observations of phenologic and cold hardiness variations reported

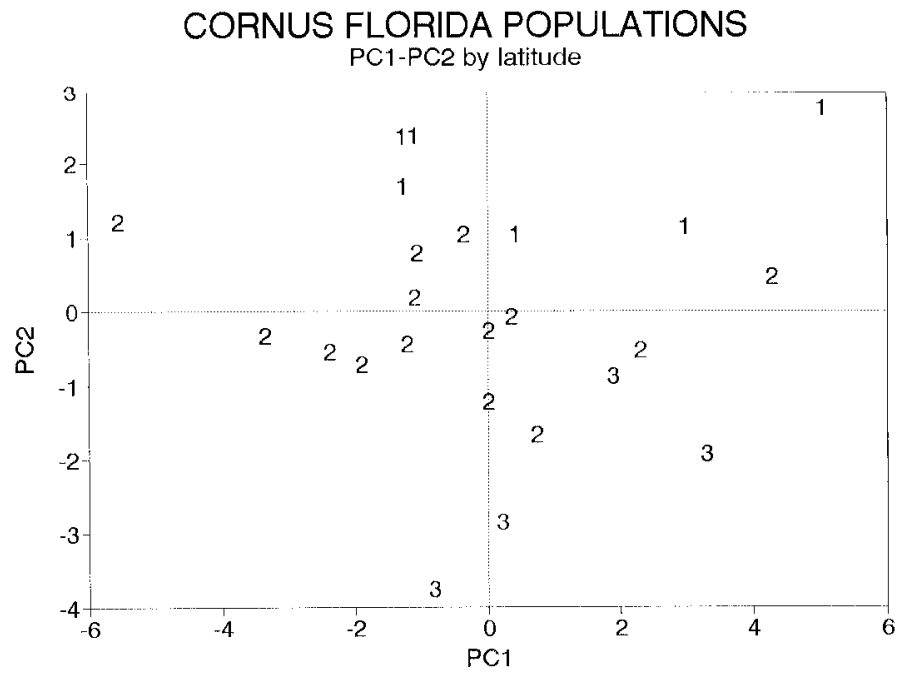

Fig. 3. Relationship between flower bud characters represented by PC2 (y-axis), and latitude of 24 Cornus florida populations in a provenance plantation. Latitude designations: $1=>40^{\circ}, 2=36^{\circ}-40^{\circ}, 3=<40^{\circ}$. in C. florida (Dirr, 1990; Heatley, 1986). When woody plant species with southern origins are moved northward, they will often respond with an extended growth period in late summer, delaying floral initiation and dormancy (Kozlowski et al., 1991). This may negatively influence cold acclimation. Therefore, many of the growth and cold-hardiness problems affecting dogwood trees in northern landscapes may be associated with their southern origins.

However, while $C$. florida is insect pollinated and seed dispersal is accomplished through animal ingestion and gravity, it still has the potential for long-distance seed dispersal. Depending on latitude, ripening of $C$. florida fruit occurs between September and November. The increased quantity of fruit consumed during the migratory period (Stiles, 1980) has the potential to enhance gene flow between populations over a greater distance. This scenario seems to contradict the review by Hamrick and Loveless (1986) which found surprising levels of differentiation among plant populations with animal-ingested dispersal mechanisms. However, given the two possible mechanisms for gene flow, animalingested seed dispersal would likely yield the greatest long distance gene transfer between $C$. florida populations.

Contradictory levels of genetic variation were revealed by isozyme and morphological analysis. Isozyme analysis showed low levels of genetic variation while the PC analysis revealed a considerable amount of genetic variation with a significant relationship between flower bud morphology and geographic origin. The inconsistency in genetic variation revealed by isozyme and morphological analysis suggests that the variability at the isozyme loci examined in this study may underestimate the amount of variability in the entire genome. Several studies indicate that isozyme loci are not under the same selection pressures as quantitative traits and that quantitative traits often reveal geographic 
patterns (Muona, 1989). The results of this study concur with these previous investigations and suggest that the considerable variation in morphological traits, especially flower bud characters, is a more representative measure of genetic variation and ecotypic adaptation in $C$. florida populations.

\section{Literature Cited}

Blue, M.P. and R.J. Jensen. 1988. Positional and seasonal variation in oak (Quercus; Fagaceae) leaf morphology. Amer. J. Bot. 75(7):939-947.

Bousquet, J., W.M. Cheliak, and M. LaLonde. 1987. Genetic differentiation among 22 mature populations of green alder (Alnus crispa) in central Quebec. Can. J. For. Res. 17:219-227.

Brown, A.H.D. 1979. Enzyme polymorphism in plant populations. Theor. Popul. Biol. 15:1-42.

Clayton, J.W. and D.N. Tretiak. 1972. Amine-citrate buffers for $\mathrm{pH}$ control in starch gel electrophoresis. J. Fish. Res. Board Can. 29:11691172.

Culpepper, J.H, L.A. Sayavedra-Soto, B.J. Bassam, and P.M. Gresshoff. 1991. Characterization of Cornus (Dogwood) genotypes using DNA fingerprinting. J. Amer. Soc. Hort. Sci. 116:1103-1107.

Dirr, M.A. 1990. Manual of woody landscape plants: Their identification, ornamental characteristics, culture, propagation, and uses. Stipes Publishing, Champaign, Ill.

Elias, T.S. 1987. The complete trees of North America. Gramercy Publishing, New York.

Gunatilleke, C.V.S. and I.A.U.N. Gunatilleke. 1984. Some observations on the reproductive biology of three species of Cornus (Cornaceae). J. Arnold Arboretum 65:419-427.

Hamrick, J.L. and M.J. Godt. 1989. Allozyme diversity in plant species, p. 43-63. In: A.H.D. Brown, M.T. Clegg, A.L. Kahler, and B.S. Weir (eds.). Plant population genetics, breeding, and genetic resources. Sinauer Associates, Sunderland, Mass.

Hamrick, J.L. and M.D. Loveless. 1986. The influence of seed dispersal mechanisms on the genetic structure of plant populations, p. 211-223. In: A. Estrada and T.H. Fleming (eds.). Frugivores and seed dispersal. Dr. W. Junk Publishers, Dordrecht.

Hamrick, J.L., Y.B. Linhart, and J.B. Mitton. 1979. Relationships between life history characteristics and electrophoretically detectable genetic variation in plants. Annu. Rev. Ecol. Syst. 10:173-200.
Heatley, R.C. 1986. Genetic variation of Cornus florida in a Michigan provenance test. PhD diss., Michigan State Univ., East Lansing.

Hokanson, S.C., J.G. Isebrands, R.J. Jensen, and J.F. Hancock. 1993. Isozyme variation in oaks of the Apostle Islands in Wisconsin: Genetic structure and levels of inbreeding in Quercus rubra and Q. ellipsoidalis (Fagaceae). Amer. J. Bot. 80(1):1349-1357.

Kephart, S.R. 1990. Starch gel electrophoresis of plant isozymes: A comparative analysis of techniques. Amer. J. Bot. 77(5):693-712.

Kozlowski, T.T., P.J. Kramer, and S.G. Pallardy. 1991. The physiological ecology of woody plants. Academic Press, San Diego.

Loveless, M.D. and J.L. Hamrick. 1984. Ecological determinants of genetic structure in plant populations. Ann. Rev. Ecol. Syst. 15:65-95. Muona, O. 1989. Population genetics in forest tree improvement, p. 282 298. In: A.H.D. Brown, M.T. Clegg, A.L. Kahler, and B.S. Weir (eds.). Plant population genetics, breeding and genetic resources. Sinauer, Sunderland, Mass.

Nei, M. 1978. Estimation of average heterozygosity and genetic distance from a small number of individuals. Genetics 89:583-590.

Santamour, F.S. and A.J. McArdle. 1989. Susceptibility of flowering dogwood of various provenances to dogwood anthracnose. Plant Dis. 73(7):590-591.

Scandalios, J.G. 1969. Genetic control of multiple molecular forms of enzymes in plants: A review. Biochem. Genet. 3:37-79.

Soltis, D.E., C.H. Haufler, D.C. Darrow, and J. Gastony. 1983. Starch gel electrophoresis of ferns: A compilation of grinding buffers, gel and electrode buffers, and staining schedules. Amer. Fern J. 73(1):9-27.

Stiles, E.W. 1980. Patterns of fruit presentation and seed dispersal in birddisseminated woody plants in the eastern deciduous forest. Amer. Naturalist 116:670-688.

Surles, S.E., J.L. Hamrick, and B.C. Bongarten. 1989. Allozyme variation in black locust (Robinia pseudoacacia). Can. J. For. Res. 19:471-479.

Vallejos, C.E. 1983. Enzyme activity staining, p. 469-516. In: S.D. Tanksley and T.J. Orton (eds.). Isozymes in plant genetics and breeding. Part A. Elsevier, Amsterdam.

Wendel, J.F. and C.R. Parks. 1985. Genetic diversity and population structure in Camellia japonica L. (Theaceae). Amer. J. Bot. 72(1):5265.

Wendel, J.F. and N.F. Weeden. 1989. Visualization and interpretation of plant isozymes, p. 5-45. In: D.E. Soltis and P.S. Soltis (eds.). Isozymes in plant biology. Dioscorides Portland, Ore. 